\title{
The Extent of Bullying Against Students with Learning Disabilities According to the Age Variable
}

\author{
Mohamad Ahmad Saleem Khasawneh \\ King Khalid University, Saudi Arabia \\ https://orcid.org/0000-0002-1390-3765
}

\begin{abstract}
Bullying is a common behavior among school students and a serious problem addressed by many relevant stakeholders. The Ministry of Education puts plans to address this issue, but need more feedback from the field to feed its strategies and programs. Therefore, this study aims at investigating the degree of bullying among students with learning disabilities (LD) in the Asir Region and exploring the relationship between bullying and age. The study used the survey methodology to collect data, and for which a questionnaire was developed and distributed to a sample of 350 families of children with LDs enrolled in schools of Asir General Directorate of Education. The sample responses to the questionnaire were analyzed using the SPSS statistical package. The study revealed that bullying behavior was at a low level among the sample of the study. The results showed no statistically significant differences in the level of bullying among children with LDs at the basic educational stage due to the variable of age. The study concludes that awareness programs should be developed for teachers to help them identify indicators associated with bullying, in addition to future studies on the phenomenon and its relationship to other variables, such as social anxiety and emotional intelligence.
\end{abstract}

Keywords: learning disabilities; bullying; aggression; Saudi Arabia

\section{Introduction}

Bullying is a negative behavioral aspect that is spreading in schools to an extent that has exceeded parents' and teachers' expectations. Bullying is a form of unbalanced aggression inflicted repeatedly upon victims; it occurs irrespective of culture, language, race, or gender, and relies on dominance, control, and hegemony over the victim who is hurt physically, socially, and emotionally. Bullying among school students is an increasingly widespread phenomenon. It is a very serious social and personal problem that leaves negative consequences on the general school environment. It also affects the cognitive, emotional, and social development of students, and their right to learn within a safe school environment. Effective learning takes place only in an environment that 
provides its students with psychological security while protecting them from violence, danger, and threat. In addition, social factors play an important role in nurturing individuals and shaping their behavior using multiple methods in the process of growth. These methods differ from one family to another, as some families are characterized by softness and tolerance, so parents deal with their son with tolerance and acceptance of his/her ideas and aspirations. Therefore, such a child is social, cooperative, loyal, gentle, stable emotionally, and joyful while facing life with confidence (Unnever, 2005).

Some families raise their children to be authoritarian and cruel, as parents impose their opinion on children without caring about their desires and inclinations. Parents may use corporal punishment and threats as a basic method in social growth, in addition to demeaning and underestimating the child, which leads to the formation of a shy, fearful character who feels insufficient. The child's sense of rejection threatens parents' feelings of security and stimulates feelings of helplessness and frustration, which can hinder the child's interaction and compatibility with life. On the other hand, some parents may raise their children on dependence and ready-made solutions, while others may raise their children to depend on themselves (Al-Kitani, 2000). Moreover, Bullying usually occurs inside and outside the school. Schoolyards are the most common place where bullying behavior is common. It also takes place in school corridors, restrooms, and classrooms. The bullies choose their victims from students who are close to their age or younger (Vieno et al., 2011).

Bullying is increasing steadily and is becoming a dangerous educational, social, and personal problem with negative effects on the general academic environment. It also harms the cognitive, emotional, and social growth of individuals. Furthermore, it violates students' right to learn in a safe environment, which can only happen in a setting where students have a sense of psychological security against violence, danger, and threats that influence their academic achievement. This study is an attempt to assist in identifying signs of bullying against students with learning disabilities (LDs) in the Asir Region in Saudi Arabia for developing appropriate educational strategies and providing adequate materials to overcome this problem.

\section{Literature Review}

Interest in bullying started in the early seventies of the twentieth century when Dan Olweus investigated the problems faced by bullies and their victims. He pointed out that most bullies suffer from control of aggressive motives and lack of sympathy for others, and they usually look to control and not for attracting attention (Olweus \& Limber, 2010). If their behavior is neglected, they rarely stop it. Bullying behavior occurs when a child or an individual is constantly exposed to a negative behavior that causes pain resulting from an unequal power between two individuals, where the first is called a bully and the other is a victim (Starr, 2000). Bullying may take physical, verbal, or emotional forms. It also has a hidden nature, as it occurs in most schools and is difficult to perceive and discover due to the secrecy that surrounds it. Most school bullying victims 
are male and female, and they never tell anyone what happens to them (Kandemir \& Özbay, 2009).

\section{Bullying and Students with LD}

The literature presents different findings on bullying against students with LDs, which is similar to any kind of bullying practiced against regular students. One of the main determinants of the degree of bullying is age differences, as reports show that bullying against younger children is common and starts to decline when the victim id over e 8-16 years old (Fox \& Boulton, 2005). The sex difference also important in studying bullying, as boys are more inclined to behave as bullies, but both genders receive equal treatment as bullied. However, boys tend to use physical bullying while girls use bullying indirectly or in what is known as relational bullying (Duncan, 1999). Students with LDs or any kind of disability are more vulnerable to being victimized by bullies (Sharp \& Smith, 2002, 1994; Dawkins, 1996). The disabilities or the learning difficulty this category have made them an easy target for bullies. Students with LDs who study in regular schools are less protected socially, and therefore, could suffer from bullying more than other victims (Dawkins, 1996). According to O'Moore and Hillery (1989), students attending special education classrooms are easily bullied. Ziegler and Rosenstein-Manner (1991) reported that in Toronto, the rates of bullying among students with LDs are twice higher than among their regular beers.

\section{Forms of Bullying}

Bullying is prevalent in all schools with high rates that exceed the expectations of parents and teachers. Most students practice bullying, whether they are bullies, victims, or bystanders; they replace the roles of the bullied and the victim according to the different circumstances and balances of power among students (Jenkins et al., 2017). Research into bullying behavior in individuals yielded different forms (Fox \& Boulton, 2005). First, there was verbal bullying, such as insulting, cursing, threatening, and rumors. Second forms were psychological bullying, which is like ignoring, isolating the individual psychologically and socially, not paying attention, and marginalizing. Third forms include physical bullying such as severe beating, pulling hair, wounding others, breaking their organs, biting, and slapping. In most cases, physical bullying does not cause significant harm to the victim because this leads to sympathy for the victim, and thus to blaming the bully (Al-Subaihin, 2007). Fourth, social bullying, such as underestimating the victim, reducing his/her sense of self and include ignorance, isolation, the victim's removal from peers, and exclusion from school or social activities outside the school such as recreational, sports, and artistic activities (Frisen \& Holmqvist, 2010). Fifth, property damage, such as tearing clothes, damaging books, stealing and then sabotaging them, and damaging colleagues' tools such as pens and notebooks, and personal belongings were also examples of these forms (Heino et al., 2010). Finally, sexual bullying, which takes a variety of forms including sexual comments, perversions, spreading sexual rumors, direct sexual contact, and displaying sexual material such as movies and photos (Fox \& Boulton, 2005). 


\section{Previous Studies}

Few studies tackled the issue of bullying among students with LDs. However, some research from Arabic-speaking (and other) countries have touched upon this issue among non-LD students. Bradshow (2018) examined the differences in the responses of adolescents of spectators to bullying. The study used the stratification analysis to analyze if the patterns of pedestrian responses differ as a function of each of the characteristics of the student and school level. Data from 18863 high school students from 58 schools, who witnessed bullying, were used to identify five underlying categories of pedestrian behavior. Three of the categories were identified parallel to the categories that were generally identified by researchers (defender $=20.4 \%$ and submissive $=9.7 \%$, and contributor $=3.4 \%$, while two categories were also identified for pedestrians that were not previously described (limited $=64.8 \%$ and inconsistent $=1.7 \%$ ). The results indicated that the responses of the defenders were relatively low and suggested that school-level contextual factors and youth perceptions of other pedestrians' behavior and their involvement in bullying all underpin our understanding of the behavior of pedestrians from adolescents.

In Nepal, Mishra et al. (2018) investigated the level of control of bullying behavior (bullies, victims) and their contribution to symptoms of frustration and psychosomatic symptoms. The study analyzed a descriptive cross-sectional sample that consisted of students of the eighth, ninth, and tenth grades in the Municipality of Buthan in the western center of Nepal, and 405 students responded to the questionnaire. The results of the study indicated a high control of bullying $(55.8 \%)$ over the most fortunate students from the Gangati tribe, and the victims $(64.86 \%)$ belonged to the smaller Janjati tribe. It was found that bullying students were more in eighth and tenth grades while ninth-grade students were mostly victims. Bullying behavior is more prevalent in private schools than in public schools.

Laftman et al. (2018) analyzed whether bullying-related harm is associated with an increased likelihood of reporting a pessimistic future trend among school students. Data were collected from the Stockholm School Study conducted in 2016 on ninth-graders (ages 15-16 years) $(n=5144)$. Orientation and future intervention in school bullying and cyber-bullying were based on self-reports. The study used a dual logistic regression method. The results indicated that victims and vulnerable victims of school bullying and cyber-bullying were more likely to report a future pessimistic trend compared to students not involved in bullying. These links were also displayed when spotting control among school bullying and cyber-bullying in a mutual fashion. The results confirmed the importance of anti-bullying measures that target both school bullying and cyberbullying.

King (2018) measured bullying and harassing students with disabilities through school compliance in order to avoid referring the matter to the judiciary. The study adopted the method of extrapolation of previous studies on this subject and historically from the fifties until 2018, as well as reviewed several judicial rulings relating to the prosecution of students for abuse, bullying behavior, and 
sexual harassment. The study concluded that it is the duty of school officials and attorneys representing the school to safeguard students' right to quality education, and that judicial translation of the Education Law will undoubtedly represent a challenge for schools. The results also showed that despite the increasing difficulty of this task, leaders in education could meet these needs through diving deeply in all dimensions of special education laws and use of the internal and external sources available to them.

Jenkins et al. (2017) investigated the relationship between bullying experiences (e.g., bullying, victims, and advocacy) and social, emotional, and perceptual factors. The perceptual element was represented by social skills (empathy, cooperation, responsibility), the emotional aspect by emotional difficulties (personal adjustments, internal issues, and school problems), and the perceptual component by effective executive skills (self-monitoring, resilience, emotional self-regulation. Data were collected from 246 students in grades 6-8; their social/personal skills, emotional difficulties, and behavior as bullying students were assessed. The findings showed that emotional difficulties had a positive, significant relationship between boys and girls as targeted victims. Emotional difficulties were also positively and significantly linked to girls defending themselves against bullying. Social skills had a positive, significant connection with boys and girls defending themselves.

In Denmark, Talts et al. (2017) explored parents' communication with teachers and their evaluation of the values dominating the classrooms of second-grade students by using the Free from Bullying program. The theory underlying the program sought to develop children's social skills, in which parent-teacher partnerships play an important role. The program was launched in 2007 and was applied in Estonia in kindergartens starting in 2010. The application of the program yielded positive results as shown in topics of parent-teacher discussions, which focused on combining activities and bullying among students. The findings also showed that parents who were more active in enrolling their children in the Free from Bullying program were more likely to discuss aspects of the classroom's social structure with the teacher ${ }^{16}$.

Another study conducted in Egypt, Mahmood (2016) investigated the effectiveness of a counseling program for developing social intelligence in decreasing bullying among students at the elementary school stage. The study used a quasi-empirical method based on the pre-post tests, which was applied to a sample of 20 elementary school students with low social intelligence and high bullying behavior. The findings demonstrated the effectiveness of the counseling program for developing social intelligence skills in decreasing bullying behavior.

In Saudi Arabia, Sakran and Alwan (2016) investigated the factorial structure of bullying as a concept, the prevalence of this phenomenon, and its justification by students that commit bullying. The study used a scale to measure bullying among a sample of 352 students from three school stages in Saudi Arabia. The results revealed that students who bully others try to find justification for their behavior. The intermediate stage had higher rates of bullying than other elementary and secondary stages. 
In the Italian context, Menesini et al. (2015) examined the effects of individual and collective moral norms on the prediction of exposure to bullying at school. The sample consisted of 1,009 students at the secondary educational stage, who were randomly selected. The study used the individual and collective moral norms scale and exposure to bullying scale to collect data. The results suggested a positive correlational relationship between exposure to bullying in the classroom and the school environment, and a low level of individual and collective moral norms. The outcomes also imply that an increase in students' level of moral norms was a statistically significant predictor of students not bullying their peers.

Deniz and Ersoy (2016) investigated the relationship between bullying and students' level of social skills and problem-solving among teenagers. The study administered a questionnaire on bullying and the Turkish version of the Matson Evaluation of Social Skills with Youngsters (MESSY) on a sample of 392 students (210 males and 182 females). The findings showed a positive link between social skills and the sub-categories of confidence and avoidance. Furthermore, the findings showed no connection between negative degrees of social skills and the sub-categories of problem-solving, confidence, self-control, and avoidance.

Finally, Catone et al. (2017) conducted a systematic review to investigate the findings of different studies that have jointly investigated the relationship between bullying and mental disorders (including people who are fully affected by the latter). The study also aimed at framing this relationship, as well as the primary theoretical reasons for such a relationship. The result of this analysis revealed that bullying of special education students requires careful study of the developmental trajectories involved, and that research should now focus on how personal, social, and biological factors interact ${ }^{21}$.

By reviewing relevant studies, we see that bullying is associated with many variables. Some studies dealt with bullying behavior, family, school patterns in academic achievement and discipline, gender, age, and parents' immigration status. Other investigations addressed the academic concept of the self and academic performance. This review showed the need for investigating bullying behavior among students with LDs in order to provide insights for educators and decision-makers when addressing the issue of bullying in Saudi Arabia.

\section{Significance of the study}

The scientific significance of this study stems from its attempt to shed light on a vital phenomenon that is increasing in public schools in the Asir Region. In addition, this study explored the connection between bullying and its consequences on students with LDs. The practical significance of this study comes from the insights it provided for future research concerned with alleviating bullying behavior. The results are expected to benefit interested scholars by providing them with a theoretical background on the relationship between bullying and LDs, as well as a critical measure used by researchers and specialists to identify problems that students experience. 
Some studies have pointed out the role of the family in bullying behavior (Bidwell, 1997). Students that commit bullying behaviors are usually victims at home and come from families that suffer from challenges regarding the parentchild relationship, as well as social and financial hardship (Smith \& Low, 2013). Families who use bullying often lack warmth, tenderness, order at home, and have trouble sharing their feelings with others. They also describe themselves as not close to their families. Parents of bully students rarely control or monitor their children and exercise harsh, punitive measures to do so (Al-Rousan, 2016).

Despite the abundance of studies that address bullying both locally and universally, they often pay attention to its causes, consequences, or to methods of prevention and treatment. Studies on bullying among students with LDs are few in number, as well as research on social anxiety and its relationship to bullying. Therefore, this study examined the problem by exploring the rates of bullying among this category of students.

\section{Research Questions}

This study tries to answer the following two questions:

1) What is the degree of bullying among students with LDs at the basic educational stage in the Asir Region?

2) Are there statistically significant differences due to age regarding the degree of bullying among students with LDs at the basic educational stage in the Asir Region?

\section{Definition of Concepts}

Bullying: It is an unwanted, aggressive behavior resulting from a lack of balance in power between the bully and the victim. This is repeated overtime where the bully exercises direct or indirect aggression without concern or discomfort, and with an internal desire for aggression. It is defined in this study as the control of an individual or group over another individual or a group for the purpose of exercising authority and dominance, which may involve verbal or physical abuse. Bullying is defined operationally by the total score obtained by students through their responses to the questionnaire used in the study.

Students with LDs: These students show a disorder in one or more psychological processes involved in understanding and using spoken or written language, which may manifest in hearing, thinking, speech, reading, spelling, and arithmetic. These conditions are due to causes pertaining to minimal brain dysfunction, but not relating to mental, hearing, visual, or other handicaps (Assarayreh, 2007). Students with LDs are defined in the current study as those students who have been officially diagnosed and identified by the Ministry of Education as students with LDs and are enrolled in LD (resource) rooms at schools in the General Directorate of Education in Asir Region. 


\section{Methodology \\ Sampling}

The population of the present study consisted of all (350) students with LDs enrolled in the resource rooms from 4-6 grades at schools in the General Directorate of Education in the Asir Region. The sample consisted of the same research population. The authors distributed 350 questionnaires to measure the level of bullying behavior. Due to the reading and writing difficulties experienced by students with LDs, the author obtained information on the students' reading and writing difficulties with the help of the special education teacher, the Arabic language teacher, and the physical education teacher in each school.

\section{Instrument}

The authors developed a scale to measure the bullying phenomenon among students with LDs. This scale took the form of a questionnaire prepared after reviewing the theoretical literature on bullying behavior, and also after reading Arabic-language and foreign studies on issues (Talts et al., 2017; Mahmood 2016; Jaradat, 2008; Abu Ghazal, 2009). The author conducted an exploratory study that included a question for schoolteachers in Asir Region: What are the antisocial (bullying) practices observed in students with LDs? The answers were used to tailor the content of each paragraph of the questionnaire about bullying. In light of the above-mentioned details, the authors prepared the dimensions and items of the questionnaire. The questionnaire consisted of 26 paragraphs distributed over two dimensions: verbal and physical bullying.

\section{Validity}

The authors verified the scale's validity by content and construct validity.

\section{Content Validity}

Content validity was confirmed by presenting the scale to 10 experienced, competent arbitrators from the faculty members at King Khalid University, Jeddah University, and the Hashemite University. The authors relied on the consensus of $80 \%$ of the arbitrators for each item; that is, the observations of more than $20 \%$ served as a sufficient criterion to modify, delete, or add some paragraphs. The final version of the scale contained 26 paragraphs.

\section{Construct Validity}

The authors verified indicators of the construct validity by conducting an exploratory study on a sample of 40 students from a population similar to that of the research population. After applying the questionnaire to the sample, the correlation coefficients between the scale items, as well as to the total score, were calculated. The coefficient of discrimination for each item was also calculated. The discrimination coefficient represents an indicator of validity for each item and the extent that each item/paragraph of the questionnaire is correlated to the dimension it attempts to measure. The paragraphs' correlation coefficients with the dimension ranged from (0.402-0.854) as displayed in Table 1. 
Table 1: Correlation coefficients between the items and the dimension in question on the scale of perceptions of bullying

\begin{tabular}{|c|c|c|c|}
\hline \multicolumn{2}{|r|}{ Physical bullying } & \multicolumn{2}{|r|}{ Verbal bullying } \\
\hline Item & $\begin{array}{c}\text { Correlation coefficient with } \\
\text { the dimension }\end{array}$ & Item & $\begin{array}{c}\text { Correlation coefficient with } \\
\text { the dimension }\end{array}$ \\
\hline 1. & **0.694 & 14. & **0.804 \\
\hline 2. & $* * 0.738$ & 15. & $* * 0.783$ \\
\hline 3. & $* * 0.688$ & 16. & $* * 0.754$ \\
\hline 4. & **0.811 & 17. & **0.402 \\
\hline 5. & **0.541 & 18. & **0.854 \\
\hline 6. & $* * 0.584$ & 19. & **0.749 \\
\hline 7. & $* * 0.768$ & 20. & **0.813 \\
\hline 8. & $* * 0.816$ & 21. & **0.792 \\
\hline 9. & $* * 0.726$ & 22. & $* * 0.832$ \\
\hline 10. & $* * 0.771$ & 23. & **0.753 \\
\hline 11. & $* * 0.754$ & 24. & **0.781 \\
\hline 12. & $* * 0.814$ & 25. & $* 0.790$ \\
\hline 13. & $* * 0.724$ & 26. & $* * 0.786$ \\
\hline
\end{tabular}

**Statistically significant at the level of significance $(0.01 \%)$

Table 1 demonstrates that all correlation coefficients were of acceptable degrees, and of statistical significance at the level of $0.01 \%$; thus, no item of the scale was deleted.

\section{Reliability}

The Test-retest method was used to check the scale's reliability by conducting a pilot study on a sample of 30 students with LDs. The two-week interval between the two applications was carried on. Pearson Correlation Coefficient between the scores for the two applications was calculated. The correlation coefficient obtained through the test-retest method for the scale was 0.864 . The stability coefficient was calculated using Cronbach's alpha, and the stability coefficient via internal consistency was 0.841 , indicating that the scale had an appropriate level of reliability, as shown in Table 2.

Table 2: Reliability coefficient via internal consistency, Cronbach's alpha, and the test-retest method for the study's dimensions and the whole score of the scale

\begin{tabular}{|l|c|c|}
\hline \multicolumn{1}{|c|}{ Dimension } & Test-retest reliability & $\begin{array}{c}\text { Reliability of internal } \\
\text { consistency }\end{array}$ \\
\hline Physical bullying & 0.792 & 0.816 \\
\hline Verbal bullying & 0.853 & 0.835 \\
\hline The scale as a whole & 0.864 & 0.841 \\
\hline
\end{tabular}

Based on the methods employed, through which the authors extracted validity and reliability indicators, it is clear that the scale has acceptable and suitable indicators for the current study. 


\section{Findings}

The first question of this study was "What is the degree of bullying among students with LDs at the basic educational stage in Asir Region?" To answer this question, means and standard divisions of the level of bullying behavior among children with LDs were obtained as illustrated in Table 3.

Table 3: Mean scores and standard deviations of the level of bullying behavior among students with LDs at the basic educational stage in Asir Region, ranked in descending order

\begin{tabular}{|c|c|c|c|c|c|}
\hline $\begin{array}{c}\text { Rank } \\
\text { (order) }\end{array}$ & Number & Domain & Mean Score & $\begin{array}{c}\text { Standard } \\
\text { Deviation }\end{array}$ & Degree \\
\hline 1 & 1 & Physical bullying & 2.19 & 0.321 & Low \\
\hline 2 & 2 & Verbal bullying & 2.05 & 0.313 & Low \\
\hline & The total score of the bullying \\
scale & 2.12 & 0.263 & Low \\
\hline
\end{tabular}

Table 3 shows the mean scores and standard deviations of the level of bullying behavior among children with LDs at the basic educational stage in the Asir Region. The overall level of bullying behavior was low. The mean score of bullying, in general, was 2.12, and the physical bullying dimension was in the first rank, with the highest mean score of 2.19 , followed by the verbal bullying dimension, with a mean score of 2.05. The mean score and standard deviations of both dimensions of the questionnaire were calculated. Table 4 presents the results related to the first dimension, which is physical bullying.

Table 4: Arithmetic means and standard deviations of the level of physical bullying behavior

\begin{tabular}{|l|c|c|c|c|c|}
\hline Rank & $\begin{array}{c}\text { Paragraph } \\
\text { no. }\end{array}$ & Paragraph & $\begin{array}{c}\text { Mean } \\
\text { Score }\end{array}$ & $\begin{array}{c}\text { Standard } \\
\text { Deviation }\end{array}$ & Degree \\
\hline 1 & 7 & $\begin{array}{c}\text { He pushes his classmate and sits } \\
\text { down in his place. }\end{array}$ & 2.32 & 1.247 & Low \\
\hline 2 & 6 & $\begin{array}{c}\text { He hinders his classmate, who } \\
\text { passes in front of him. }\end{array}$ & 2.31 & 1.036 & Low \\
\hline 3 & 4 & $\begin{array}{c}\text { He twists his classmate's arm and } \\
\text { shoves him into a corner. }\end{array}$ & 2.30 & 1.063 & Low \\
\hline 4 & 3 & $\begin{array}{c}\text { He creates a reason to argue with a } \\
\text { classmate who is less powerful than } \\
\text { him. }\end{array}$ & 2.29 & 1.149 & Low \\
\hline 5 & 13 & He bites a classmate. & 2.26 & 1.96 & Low \\
\hline 6 & 2 & $\begin{array}{c}\text { He pinches a classmate and pulls his } \\
\text { hair tightly. }\end{array}$ & 2.23 & 1.126 & Low \\
\hline 7 & 1 & He hits his classmates. & 2.17 & 1.126 & Low \\
\hline 8 & 12 & He spits on a classmate. & 2.15 & 1.071 & Low \\
\hline 9 & 11 & $\begin{array}{c}\text { He scratches a classmate with a } \\
\text { sharp instrument. }\end{array}$ & 2.14 & 1.096 & Low \\
\hline 10 & 10 & He tears the shirt of a classmate. & 2.14 & 1.127 & Low \\
\hline 11 & 9 & $\begin{array}{c}\text { He holds his classmate by the neck } \\
\text { and tries to stifle him. }\end{array}$ & 2.10 & 1.121 & Low \\
\hline 12 & 8 & He throws his classmate down and & 2.06 & 1.106 & Low \\
\hline
\end{tabular}




\begin{tabular}{|l|c|c|c|c|c|}
\hline & & steps on his stomach. & & & \\
\hline 13 & 5 & $\begin{array}{c}\text { He swoops down on his classmate } \\
\text { and hits him with instruments such } \\
\text { as a stick or a ruler. }\end{array}$ & 2.00 & 1.138 & Low \\
\hline \multicolumn{2}{|r|}{ The total score of physical bullying } & 2.19 & 0.321 & Low \\
\hline
\end{tabular}

Table 4 shows the mean scores of the paragraphs related to the physical bullying behavior. Paragraph (7) came in the first order with a mean score of 2.32 and paragraph (5) came in last, with a mean score of 2.00.

To detect the level of verbal bullying, the mean scores and standard deviations of the level of verbal bullying behavior among children with LDs at the basic educational stage in the Asir Region were obtained, as displayed in Table 5.

Table 5: Arithmetic means and standard deviations of verbal bullying items, arranged in descending order according to the arithmetic mean

\begin{tabular}{|l|c|c|c|c|c|}
\hline Rank & $\begin{array}{c}\text { Paragraph } \\
\text { no. }\end{array}$ & Paragraph & $\begin{array}{c}\text { Mean } \\
\text { Score }\end{array}$ & $\begin{array}{c}\text { Standard } \\
\text { Deviation }\end{array}$ & Degree \\
\hline 1 & 19 & $\begin{array}{c}\text { He always threatens his } \\
\text { classmates. }\end{array}$ & 2.32 & 0.890 & Low \\
\hline 2 & 18 & $\begin{array}{c}\text { He tells lies and rumors to a } \\
\text { classmate. }\end{array}$ & 2.21 & 0.911 & Low \\
\hline 3 & 22 & $\begin{array}{c}\text { He blackmails a student in front of } \\
\text { his classmates. }\end{array}$ & 2.15 & 0.937 & Low \\
\hline 4 & 17 & $\begin{array}{c}\text { He deliberately reveals others' } \\
\text { personal secrets. }\end{array}$ & 2.12 & 0.969 & Low \\
\hline 5 & 15 & $\begin{array}{c}\text { He makes a classmate look foolish } \\
\text { in front of others. }\end{array}$ & 2.09 & 0.974 & Low \\
\hline 6 & 14 & $\begin{array}{c}\text { He curses his classmates, using } \\
\text { obscene words. }\end{array}$ & 2.06 & 0.974 & Low \\
\hline 7 & 20 & $\begin{array}{c}\text { He disturbs a classmate by phone } \\
\text { calls. }\end{array}$ & 2.05 & 0.990 & Low \\
\hline 8 & 26 & $\begin{array}{c}\text { He makes up stories to incite } \\
\text { students against each other. }\end{array}$ & 2.02 & 0.779 & Low \\
\hline 9 & 16 & $\begin{array}{c}\text { He calls a classmate an obscene } \\
\text { name. }\end{array}$ & 2.00 & 0.934 & Low \\
\hline 10 & 25 & $\begin{array}{c}\text { He spoils a team game for his } \\
\text { classmates. }\end{array}$ & 1.97 & 1.061 & Low \\
\hline 11 & 24 & $\begin{array}{c}\text { He accuses a classmate of actions } \\
\text { he did not commit to keep others } \\
\text { away from him. }\end{array}$ & 1.95 & 0.913 & Low \\
\hline 12 & 23 & $\begin{array}{c}\text { Encourages rebellion against the } \\
\text { teacher among a group of students } \\
\text { to incite a quarrel. }\end{array}$ & 1.92 & 0.919 & Low \\
\hline 13 & 21 & $\begin{array}{c}\text { He incites some students against } \\
\text { other students. }\end{array}$ & 1.88 & 0.823 & Low \\
\hline
\end{tabular}

Table 5 shows the mean scores and standard deviations of paragraphs related to verbal bullying. Paragraph (19) came in the first order with a mean score of 2.23, 
followed by paragraph (18), with a mean score of 2.21. Paragraph (21) came in the last order with a mean score of 1.88 .

The second question this study was "Are there statistically significant differences due to age regarding the degree of bullying among students with LDs at the basic educational stage in Asir Region?" To answer this question, the authors used a t-test for independent samples as shown in Table 6.

Table 6: The results of the t-test to identify the difference insignificance in the degree of bullying due to age among children with LDs at the basic educational stage in Asir Region

\begin{tabular}{|c|c|c|c|c|c|c|c|}
\hline Domain & $\begin{array}{l}\text { Age } \\
\text { group }\end{array}$ & Number & $\begin{array}{l}\text { Mean } \\
\text { scores }\end{array}$ & $\begin{array}{l}\text { Standard } \\
\text { deviation }\end{array}$ & $\begin{array}{c}\text { t- } \\
\text { value }\end{array}$ & $\begin{array}{c}\text { Degree } \\
\text { of } \\
\text { freedom }\end{array}$ & $\begin{array}{l}\text { Level of } \\
\text { significance }\end{array}$ \\
\hline \multirow{2}{*}{$\begin{array}{l}\text { Physical } \\
\text { bullying }\end{array}$} & $\begin{array}{c}\text { From } \\
6-9\end{array}$ & 150 & 2.17 & 0.338 & -1.149 & 348 & 0.252 \\
\hline & $\begin{array}{l}\text { From } \\
10-12\end{array}$ & 200 & 2.21 & 0.307 & & & \\
\hline \multirow{2}{*}{$\begin{array}{c}\text { Verbal } \\
\text { bullying }\end{array}$} & $\begin{array}{c}\text { From } \\
6-9\end{array}$ & 150 & 2.07 & 0.308 & 0.964 & 348 & 0.336 \\
\hline & $\begin{array}{l}\text { From } \\
10-12\end{array}$ & 200 & 2.04 & 0.317 & & & \\
\hline \multirow{2}{*}{$\begin{array}{c}\text { Bullying } \\
\text { scale as a } \\
\text { whole }\end{array}$} & $\begin{array}{c}\text { From } \\
6-9\end{array}$ & 150 & 2.12 & 0.272 & -0.123 & 348 & 0.902 \\
\hline & $\begin{array}{l}\text { From } \\
10-12\end{array}$ & 200 & 2.12 & 0.257 & & & \\
\hline
\end{tabular}

Table 6 indicates no statistically significant differences in the extent of bullying due to age among children with LDs at the basic educational stage. The value of the significance level for the dimensions of the questionnaire was 0.252 and 0.336 for physical bullying and verbal bullying, respectively, and 0.902 for bullying as a whole.

\section{Discussion}

The first research question: "What is the degree of bullying among students with LDs at the basic educational stage in Asir Region?"

The results of the mean scores and standard deviations regarding the level of bullying behavior among students with LDs revealed that bullying behavior was low. In terms of bullying as a whole, the mean score was 2.12. Physical bullying came in the first order with the highest mean score of 2.19 , followed by verbal bullying in second place, with a mean score of 2.05. The low level of bullying among students with LD could be explained by the extensive counseling programs run by the Ministry of Education (represented by the General Directorate of Education in the Asir region). The Ministry is keen to provide different schools in the area with LD specialists to handle the various psychological and behavioral disorders experienced by students with LDs. Such specialists contribute to the treatment of many behavioral disorders, including bullying, which led to a decline in its level among the participants in the sample. This low level of bullying can also be explained by the use of modem educational disciplinary techniques (which are free from physical punishment) 
in different schools. Such techniques have deterred many students from bullying their classmates.

The second research question: "Are there statistically significant differences due to age regarding the degree of bullying among students with LDs at the basic educational stage in Asir Region?"

The results of the T-test on the impact of age on the extent of bullying revealed no statistically significant differences in the degree of bullying among children with LDs at the basic educational stage. The high attention given to students with LDs, through counseling programs in different schools in the Asir Region helped in reducing the level of bullying in general without differences in age groups. It is indicated that such programs provided to students treat age groups equally and without discrimination between students, which contributed to reducing bullying among this sample.

\section{Conclusion and Recommendations}

This study aimed at investigating the levels of bullying among students with LDs in the basic stage in the Asir region in Saudi Arabia. The study concluded low levels of verbal and physical bullying among students. The researchers attributed this conclusion to the extensive counseling programs prepared and implemented by the Ministry of Education to support LDs students and prevent bullying. In light of the findings, the authors recommend the following:

- Developing awareness programs for teachers to identify the educational and demographic indicators that accompany bullying.

- Supporting counseling programs directed toward students in primary schools in general, and resource room students in particular.

- Conducting more studies on bullying and its relationship with other variables, such as social anxiety and emotional intelligence.

\section{Limitations}

The study was limited to students with LDs in grades 4-6 enrolled in resource rooms at schools in the General Directorate of Education in the Asir Region in the second semester of the academic year 2017/2018.

\section{Acknowledgments}

This study was sponsored by the Research Group Program of the Scientific Deanship at King Khalid University, Kingdom of Saudi Arabia (R.G.P.IL34L40).

\section{References}

Abu Ghazal, M. (2009). Bullying and its relation with a feeling of solitude and social support. The Jordanian Journal of Educational Sciences, Yarmouk University, 2, 89103.

Al-Kitani, F. (2000). Parental Attitudes in socialization and its relationship to children's fears. Amman: Dar El-Shorouk.

Al-Rousan, F. (2016). Psychology of exceptional children. Amman: Dar Alfeker.

Al-Subaihin, A. (2007). The effect of a behavioral, emotional, rational counseling program in reducing the bullying behavior of students in the upper basic stage (Ph.D. thesis). Yarmouk University, Irbid, Jordan. 
Assarayreh, M. (2007). Differences in the self-esteem, the family and social relationships, the Temperament, the leadership, and the school achievement between the bullying students and their victims and the normal students in the adolescent stage (Ph.D. Dissertation). University of Amman for Higher Studies, Amman, Jordan.

Bidwell, N. M. (1997). The nature and prevalence of bullying in elementary schools. Saskatchewan School Trustees Association.

Bradshow, C. (2018). Examining Variation in Adolescent Bystanders' Responses to Bullying. School Psychology Review, 47(1), 18-33. https://doi.org/10.17105/SPR2017-0081.V47-1

Catone, G., Marwaha, S., Lennox, B., \& Broome, M. R. (2017). Bullying victimization and psychosis: the interdependence and independence of risk trajectories. BJPsych Advances, 23(6), 397-406. https://doi.org/10.1192/apt.bp.116.016584

Dawkins, J. L. (1996). Bullying, physical disability, and the pediatric patient. Developmental Medicine $\mathcal{E} \quad$ Child Neurology, 38(7), 603-612. https:// doi.org/10.1111/j.1469-8749.1996.tb12125.x

Deniz, M., \& Ersoy, E. (2016). Examining the Relationship of Social Skills, Problem Solving, and Bullying in Adolescents. International Online Journal of Educational Sciences, 8(1). http://dx.doi.org/10.15345/iojes.2016.01.001

Duncan, N. (1999). Sexual bullying: gender conflict and pupil culture in secondary schools. Psychology Press.

Fox, C. L., \& Boulton, M. J. (2005). The social skills problems of victims of bullying: Self, peer, and teacher perceptions. British Journal of Educational Psychology, 75(2), 313-328. https:/ / doi.org/10.1348/000709905X25517

Frisen, A., \& Holmqvist, K. (2010). Adolescents' own suggestions for bullying interventions at age 13 and 16. Scandinavian journal of psychology, 51(2), 123-131. https://doi.org/10.1111/j.1467-9450.2009.00733.x

Heino, K., Frodj, S. \& Marttnen, M. (2010). Involvement in Bullying and Depression in Middle and High School Students. European Child-Adolescent Psychiatry, 19, 45-55.

Ireland J. L. (2002). Social self-esteem and self-reported bullying behavior among adult prisoners. Aggressive Behavior: Official Journal of the International Society for Research on Aggression, 28(3), 184-97. https://doi.org/10.1002/ab.90021

Jaradat, A. (2008). Bullying among the students of basic schools: Its origin and related factors. The Jordanian Journal on Educational Sciences, Yarmouk University.

Jenkins, L. N., Demaray, M. K., \& Tennant, J. (2017). Social, emotional, and cognitive factors associated with bullying. School psychology review, 46(1), 42-64. http://dx.doi.org/10.1080/02796015.2017.12087609.

Kandemir, M., \& Özbay, Y. (2009). Interactional effect of perceived emphatic classroom atmosphere and self-esteem on bullying. Elementary Education Online, 8(2), 322333.

King, B. (2018). Addressing the Bullying and Harassment of Students with Disabilities through School Compliance to Avoid Litigation. Brigham Young Education \& Law Journal, 1, 67-88.

Laftman, S., Alm, S., Sandahl, J., \& Modin, B. (2018). Future Orientation among Students Exposed to School Bullying and Cyberbullying Victimization. International Journal of Environmental Research and Public Health. 15(605), 1-12. http://dx.doi.org/10.3390/ijerph15040605

Mahmood, M. (2016). Effectiveness of counseling program for developing the social intelligence skills in decreasing school bullying behavior among pupils of elementary educational stage. Alhekmah Journal for Educational and Psychological Studies, Algiers, 7, 289-304. 
Menesini, E., Palladino, B. E., \& Nocentini, A. (2015). Emotions of moral disengagement, class norms, and bullying in adolescence: A multilevel approach. Merrill-Palmer Quarterly, 61(1),

124-143. http://dx.doi.org/10.13110/merrpalmquar1982.61.1.0124.

Mishra, D., Thapa, T., Marahatta, S., \& Mahotra, A. (2018). Bullying Behavior and Psychosocial Health - A Cross-sectional Study among School Students of Pyuthan Municipality. Journal of Nepal Health Research Council, 16(38), 73-78. https:// doi.org/10.3126/jnhrc.v16i1.19370

O'Moore, A. M., \& Hillery, B. (1989). Bullying in Dublin schools. The Irish Journal of Psychology, 10(3), 426-441.

Olweus, D., \& Limber, S. P. (2010). Bullying in school: evaluation and dissemination of the Olweus Bullying Prevention Program. American Journal of Orthopsychiatry, 80(1), 124.

Sakran, A., \& Alwan, I. (2016). The factorial construction of the school bullying phenomenon as an integrative concept and its prevalence and justification among students of the public education in Abha. Journal of Special Education, Center For Educational, Psychological, and Environmental Information at the College of Education, Zaqazeeq, Egypt, 16, 1-60.

Sharp, S., \& Smith, P. (2002). School bullying: Insights and perspectives. Routledge.

Smith, B. H., \& Low, S. (2013). The role of social-emotional learning in bullying prevention efforts. Theory Into Practice, 52(4), 280-287. https://doi.org/10.1080/00405841.2013.829731

Starr, L. (2000). Sticks and stones and names can hurt you: - De-Myth-tidying the classroom bully. Education word. Retrieved October 122019 from http:/ / www.peelearlyyears.com/pdf/Sticks\%20and\%20Stones\%20and\%20Nam es\%20Can\%20Hurt\%20You.pdf

Talts, L., Piht, S., \& Muldma, M. (2017). Family-Teacher Partnership in Fostering the Development of Children's Social Skills using the Bullying Prevention Programme" Free From Bullying" in Estonian Schools. Problems of Education in the 21st Century, 75(1).

Unnever, J. D. (2005). Bullies, aggressive victims, and victims: Are they distinct groups?. Aggressive Behavior: Official Journal of the International Society for Research on Aggression, 31(2), 153-171. https://doi.org/10.1002/ab.20083

Vieno, A., Gini, G., \& Santinello, M. (2011). Different forms of bullying and their association with smoking and drinking behavior in Italian adolescents. Journal of School Health, 81(7), 393-399. https://doi.org/10.1111/j.1746-1561.2011.00607.x

Ziegler, S., \& Rosenstein-Manner, M. (1991). Bullying at School: Toronto in an International Context. Research Services No. 196. 